DOI: $10.5937 /$ halo $27-30859$

UDC: 615.282 .015

Stanojković T, i sar

Peroralna primena

itrakonazola i hidroksi-

itrakonazola. Halo 194.

2021; 27(1):7-18.

Rad primljen: 14.02.2021.

Prihvaćen: $\quad 09.03 .2021$

\section{Korespodencija:}

Nemanja Rančić

VMA, Beograd

Srbija

Mob.tel: +38163-8524443

Email: nece84@hotmail.com
ORIGINALNI RAD

\section{KONCENTRACIJE ITRAKONAZOLA I HIDROKSI-ITRAKONAZOLA NAKON ORALNE PRIMENE LEKA KOD ZDRAVIH LJUDI: UTICAJ POLA}

\author{
Tijana STANOJKOVIĆl, Milijana MILJKOVIĆ ${ }^{1,2}$, Nemanja RANČIĆ $\dot{C}^{1,2}$, \\ Aleksandra KOVAČEVIĆ ${ }^{1,2}$, Viktorija DRAGOJEVIĆ-SIMIĆ ${ }^{1,2}$
}

${ }^{1}$ Medicinski fakultet Vojnomedicinske akademije Univerziteta odbrane u Beogradu, Beograd, Srbija. ${ }^{2}$ Centar za kliničku farmakologiju, Vojnomedicinska akademija,

Beograd, Srbija

\section{SAŽETAK}

Uvod: Itrakonazol je antigljivični lek iz grupe triazola. Nakon peroralne primene, on se brzo resorbuje, ali mu je biološka raspoloživost smanjena zbog intenzivnog efekta prvog prolaza kroz jetru. Nastanak velikog broja metabolita, uključujući i najznačajniji hidroksi-itrakonazol, odvija se uz pomoć citohrom P450 izoforme CYP3A4. Na varijabilnost farmakokinetike itrakonazola utiče veliki broj nedovoljno poznatih faktora. Cilj rada je bio da se ispita uticaj pola na koncentracije itrakonazola i hidroksi-itrakonazola u plazmi zdravih odraslih osoba nakon peroralne primene leka.

Metode: Sprovedena je klinička farmakokinetska studija u kojoj je učestvovalo 22 odraslih zdravih muških ispitanika i 16 ženskih kod kojih je peroralno primenjen itrakonazol u jednoj dozi od 100mg. Uzorci krvi su uzeti pre primene leka, kao i u odgovarajućim vremenskim intervalima do 72 sata nakon toga. Koncentracije leka i metabolita su određivane primenom validirane metode tečne hromatografije sa masenom spektrometrijskom detekcijom, a njihovi farmakokinetski parametri korišćenjem Kinetica programa, verzija 5.0: $\mathrm{C}_{\max }, \mathrm{T}_{\max }, \mathrm{PIK}_{(0-72)}$, PIK $_{(0-\infty)}, \mathrm{T}_{1 / 2}$ i K $\mathrm{K}_{\mathrm{e}}$.

Rezultati: Kod ispitanica vrednosti medijane koncentracija i itrakonazola i hidroksiitrakonazola su bile manje u odnosu na muškarce u toku celog posmatranog perioda. Takođe, izračunete vrednosti medijana parametara resorpcije - Cmax, $\mathrm{PIK}_{(0-72)}$ i $\mathrm{PIK}_{(0-\infty)}$ su bile statistički značajno manje i za lek $(\mathrm{p}=0,005,0,036$ i 0,036$)$ i za metabolit $(\mathrm{p}=0,004,0,010 \mathrm{i}$ $0,044)$ kod žena. Parametri eliminacije $-\mathrm{T}_{1 / 2}$ i Ke se nisu razlikovali među polovima. Zaključak: Žene su nakon peroralne primene leka u manjem stepenu izložene itrakonazolu i njegovom aktivnom metabolitu u odnosu na muškarce, kao rezultat manje bioraspoloživosti ovog leka, uključujući i intenzivniji presistemski metabolizam usled veće ekspresije i/ili aktivnosti izoforme enzima koji ga metaboliše, a što bi bilo neophodno potvrditi farmakogenomskim analizama.

Ključne reči: itrakonazol; hidroksi-itrakonazol; koncentracije leka, zdravi ispitanici, pol.

\section{Uvod}

Dobrim poznavanje farmakokinetike (FK) i farmakodinamike leka prilikom primene $\mathrm{u}$ različitim populacijama ljudi može se postići optimizacija njegove terapijske efikasnosti, uz maksimalno smanjenje neželjenih dejstava [1]. Pol osobe koja prima lek već dugo je prepoznat kao važna varijabla u istraživanjima, koja značajno utiče na klinički ishod terapije [2]. Istorijski gledano, žene su manje uključivane u klinička ispitivanja lekova zbog hormonskih promena tokom menstrualnog ciklusa, životnih događaja poput trudnoće i laktacije i upotrebe oralnih kontraceptiva i hormonske terapije [3], a takođe se u više istraživanja pokazalo da se kod njih češće registruju neželjeni efekti [4]. Međutim, intenzivna istraživanja na ovom polju i mnoga saznanja koja su stečena, a odnose se na razlike koje postoje u FK procesima kojima podleže jedan lek kod muškaraca i žena, dovela su do toga da postoji potreba da, ako je neki lek namenjen za primenu $\mathrm{u}$ oba pola, $\mathrm{u}$ njegovo istraživanje treba da budu uključeni sličan broj muških i ženskih dobrovoljaca i/ili pacijenata [5].
Farmakokinetske polne razlike koje se odnose na resorpciju leka mogu se pripisati razlikama u nivou sekrecije želudačne kiseline, a pojedine studije navode da je ona niža kod žena [6], brzini pražnjenja sadržaja iz želuca, na šta imaju uticaj polni hormone [7], sastavu duodenalnog soka [8] (kod premenopauzalnih žena povećana sekrecija bikarbonata u duodenumu u odnosu na muškarce, takođe zbog uticaja polnih hormona), nivou ekspresije P-glikoproteina u tankom crevu. Mada bi se to moglo očekivati obzirom na to da su steroidni polni hormoni supstrati za P-glikoprotein [9], to u nekim istraživanjima nije potvrđeno [10]. Za neke supstance, kao što je alkohol, značajno niža aktivnost alkoholne dehidrogenaze kod žena dovodi do njegovog znatno manjeg metabolizma prvog prolaza [11]. Estrogeni hormoni smanjuju ekspresiju alfa-1-kiselog glikoproteina zbog čega bi kod žena mogla biti veća slobodna frakcija lekova za koje je on transporter [12], dok sa druge strane povećava nivo globulina, što takođe može uticati na razlike u procesu distribucije među polovima [13]. Uticaj pola na sudbinu leka u organizmu najviše se ogleda u razlikama u metabolizmu leka. 
Studije se najviše bave citohrom 3A4 (CYP3A4) enzimskom podfamilijom, jer njeni polimorfni enzimi metabolišu najveći broj poznatih lekova. Rezultati ukazuju da žene imaju dva puta veću ekspresiju ovog enzima [14], a objašnjenja se nalaze, između ostalog, u uticaju hormona rasta [15] i steroidnih polnih hormona na pregnan-Xreceptor (PRX) [16]. U toku procesa eliminacije polne razlike se ogledaju u brzini glomerulske filtracije (GFR) i protoku krvi kroz bubrege [17, 18]. Realno je pretpostaviti da ove razlike još više dolaze do izražaja kada su u pitanju hipervarijabilni lekovi, kao što je itrakonazol, lek iz prve generacije triazolskih antimikotika $[19,20]$. Koristi se u terapiji vulvovaginalne $\mathrm{i}$ orofaringealne kandidijaze, dermatofitoza, onihomikoza, pitirijaze, ali i kod sistemskih gljivičnih infekcija (aspergiloza, kriptokokoza, kandidijaza) [19], kod imunokompromitovanih bolesnika (terapija održavanja za obolele od AIDS-a) [21] i kao prevencija gljivičnih infekcija kod produžene granulocitopenije [20]. Nakon per os primene kapsula ili tableta itrakonazola on se brzo resorbuje, ali oko 50\% leka podleže prvom prolazu kroz jetru i dejstvu efluks pumpe P-glikoprotein, što je rezultat njegove znatno smanjene biološke raspoloživosti. Itrakonazol je slaba baza i resorpciju njegove oralne formulacije (tablete i capsule) pomažu kiseli napici [22], a najveća biološka raspoloživost se postiže ako se uzme nakon kompletnog obroka [23], jer hrana pospešuje lučenje želudačne kiseline čime se povećava kiselost, a pokazano je da je itrakonazol jonizovan i rastvorljiv u vodi samo pri niskim $\mathrm{pH}$ vrednostima. Hrana smanjuje brzinu resorpcije, ali povećava maksimalne koncentracije leka u plazmi $\left(\mathrm{C}_{\max }\right)$ i stepen resorpcije, odnosno površinu ispod krive koja prikazuje promenu koncentracije leka u plazmi u funkciji vremena (PIK) nakon primene ovih farmaceutskih formulacija itrakonazola. $\mathrm{S}$ druge strane, samo $0,2 \%$ itrakonazola ostaje nevezano za proteine plazme nakon prodora u cirkulaciju, ali je njegova izrazita lipofilnost povezana sa velikim volumenom distribucije leka [24]. Metaboliše se u jetri pomoću enzima CYP3A4 i stvara se čak oko 30 metabolita, od kojih je glavni hidroksiitrakonazol koji postiže veće koncentracije u plazmi od samog itrakonazola, a antimikotična aktivnost im je slična [25]. Eliminacija itrakonazola je bifazična, sa terminalnim poluvremenom eliminacije $\left(\mathrm{t}_{1 / 2}\right)$ nakon jedne doze leka između 20 i 24 sata, dok je u stanju ravnoteže oko $30 \mathrm{~h}$ i smatra se da je ekskrecioni mehanizam itrakonazola saturabilan. Lek se eliminiše urinom i putem žuči, a eliminacija nepromenjenog leka fecesom varira između 3 i 18\% [24]. Sve ove karakteristike leka, ali i pacijenata, uključujući i pol su značajan izvor interindividualne varijabilnosti FK itrakonazola, pre svega procesa resorpcije. Šta više, kod visoko varijabilnih lekova, u koje spada i ovaj antimikotik, brzina i stepen resorpcije pokazuju veliku varijabilnost od doze do doze kod iste osobe, odnosno koeficijent varijacije unutar ispitanika je $30 \%$ ili više [26].

\section{Cilj rada}

Cilj rada je da se ispita da li postoji uticaj pola na razlike u koncentracijama itrakonazola i hidroksiitrakonazola u serumu zdravih odraslih osoba nakon peroralne primene itrakonazola, a $\mathrm{s}$ obzirom na potencijalni značaj ovog faktora, ali i poznatoj hipervarijabilnosti ovog antimikotika.

\section{Metode rada}

\section{Ispitivani lek}

U istraživanju je korišćen antimikotik itrakonazol, primenjen u jednokratnoj dozi u vidu kapsula od 100 miligrama (Sporanox ${ }^{\circledR}$ tvrde capsule).

\section{Ispitanici}

Zdravi dobrovoljci oba pola, u starosnoj dobi od 18-55 godina, sa indeksom telesne mase između 19 i 30 $\mathrm{kg} / \mathrm{m}^{2}$, koji ne puše, ne konzumiraju alkohol i nisu zloupotrebljavali lekove i psihoaktivne supstance, sa negativnim testom na trudnoću (ispitanice) i sposobni za saradnju - ispunjavali su uslove za učešće u studiji. Ispitanici su bili informisani o prirodi studije, procedurama i potencijalnim rizicima i svi su potpisali pristanak za učešće u ispitivanju. Odluka koje osobe će biti uključene $\mathrm{u}$ ispitivanje su donesene $\mathrm{u}$ periodu od 7 dana pre početka studije $\mathrm{i}$ one su se sastojale od procene kriterijuma uključenja/isključenja u studiju, anamnestičkih podataka i eventualne prethodne primene lekova, lekarskog pregleda i vitalnih znakova (telesna težina, telesna visina, arterijski krvni pritisak, srčana frekvencija, elektrokardiografski pregled i pregled po sistemima), laboratorijskih parametara (hematoloških i biohemijskih parametara dobijenih analizom krvi, biohemijskih parametara kao rezultat analize urina, ispitivanjem prisustva antitela na virus humane imunodeficijencije (HIV-1/HIV-2) i izazivača hepatitisa $\mathrm{C}(\mathrm{HCV})$, ispiti-vanje prisustva antigena izazivača hepatitisa B (HBsAg) i testa na graviditet kod žena. Kriterijumi za isključenje su bili: podaci o ranijim ili prisutnim klinički značajnim oboljenjima dobijenim na osnovu anamneze i lekarskog pregleda, podaci iz dobijenih laboratorijskih ispitivanja, podaci o zloupotrebi alkohola i psihoaktivnih supstanci, upotreba lekova u okviru 14 dana pre samog ispitivanja (izuzev oralnih kontraceptivnih sredstava kod žena), istovremeno učestvovanje u drugim kliničkim ispitivanjima, ili do 3 meseca pre početka aktuelnog ispitivanja, davanje krvi u periodu od 3 meseca pre početka istraživanja, graviditet, pozitivan test na HBsAg, anti-HCV i anti-HIV-1/HIV-2 antitela, klinički značajna reakcija na lekove u prošlosti (anafilaksa, angioedem), kao i nemogućnosti ili nespremnost na pridržavanje odredbama protokola.

\section{Dizajn studije}

U ovoj kliničkoj farmakokinetičkoj studiji uključeno je 38 zdravih odraslih osoba, 22 muškog i 16 ženskog pola. Ispitanici su, veče pre primene leka, hospitalizovani, kao i u naredna 24 sata. Ispitanici su došli u 
centar istraživanja i 36 i 72 sata nakon primene leka. Po prijemu je procenjeno zdravstveno stanje ispitanika, izmeren i zabeležen sistolni i dijastolni krvni pritisak i srčana frekvencija i ponovo uzeta kratka anamneza. Usledilo je gladovanje tokom noći ( $\geq 10$ sati) i ujutru je dat standardizovani visoko masni i visoko kalorični obrok, prema aktuelnom evropskom vodiču [27], koji je trajao oko $30 \mathrm{~min}$, i neposredno nakon koga su ispitanici dobili jednu dozu itrakonazola, kapsulu od 100 mg, koju su uzeli zajedno sa $200 \mathrm{~mL}$ vode. Negaziranu vodu su mogli da uzimaju do 2 sata pre primene leka i 2 sata nakon toga. Standardni obrok im je serviran 4; 8,5 i 13 sati nakon uzetog leka. Vitalni znaci su ispitivani i uzorci krvi su uzeti pre davanja leka i nakon toga u odgovarajućim vremenskim intervalima do 72.0 sata nakon njegove primene. Upotreba drugih lekova, ukoliko je to bilo neophodno, uz obrazloženje, kao i prisustvo neželjenih događaja koji su vezivani za itrakonazol je verifikovano pre, kao i kontinuirano posle dobijanja kapsule leka.

\section{Prikupljanje uzoraka krvi}

Od svakog ispitanika su dobijeni uzorci venske krvi (oko $5 \mathrm{~mL}$ po uzorku) iz vene podlaktice i stavljani su u epruvete sa etilendiamintetrasirćetnom kiselinom (EDTA). Prvi uzorak je uzet pre davanja leka (vreme 0.0 ), a ostali nakon toga, $\mathrm{u}$ odgovarajućim vremenskih intervalima do 72.0 časa $(1.0 ; 2.0 ; 3.0 ; 3.5 ; 4.0 ; 4.5 ; 5.0$; $5.5 ; 6.0 ; 7.0 ; 9.0 ; 12.0 ; 24.0 ; 36.0$ i 72.0). Uzorci su centrifugirani brzinom od 3000 obrtaja u minuti (rpm) u vremenu od 10 minuta, na temperaturi od $0^{\circ}$ do $4^{\circ} \mathrm{C}$. Plazma je odvojena u posebnu epruvetu, zamrznuta i skladištena na $-20^{\circ} \mathrm{C}$ do daljih analiza.

\section{Analitičke metode}

Plazmatske koncentracije itrakonazola i hidroksiitrakonazola su analizirane pomoću validiranih metoda tečne hromatografije (High Performance Liquid Chromatography-HPLC, Alliance 2695, Waters, Massachusetts, USA) sa masenom spektrometrijom (ZQ, Quattro Micro, Waters, Massachusetts, USA), kao što je to prethodno opisano [28-30].

\section{Farmakokinetska analiza}

Relevantni farmakokinetički parametri su određivani standardnom neprostornom (model - nezavisnom) analizom. Određivani parametri su bili: $\mathrm{C}_{\max }-$ maksimalna koncentracija leka u plazmi, $\mathrm{T}_{\max }$ - vreme koje je potrebno da bi se postigla koncentracija $C_{\max }$, PIK $_{(0-72)}$ - površina ispod krive koja pokazuje promenu koncentracije leka u plazmi u funkciji vremena od primene do poslednje zapažene koncentracije u vremenu, a to je u ovom istraživanju bilo 72 časa, PIK $_{(0-\infty)}$ površina ispod krive koja pokazuje promenu koncentracije leka u plazmi u funkciji vremena, sa procenom za vrednost $u$ beskonačnost, $T_{1 / 2}$-poluvreme eliminacije, $K_{e}$ - konstanta eliminacije,
Farmakokinetska analiza je urađena korišćenjem softverskog programa Kinetica software version 5.0. (Thermo Fisher Scientific Inc., Massachusetts, USA).

\section{Bezbednost primene leka}

Tokom studije je kod svih ispitanika procenjivana bezbednost primene leka, odnosno pojava neželjenih događaja i ozbiljnih neželjenih događaja. Neželjeni događaji označavaju neželjeno iskustvo koje se dogodilo $\mathrm{u}$ periodu primene leka ili neko vreme nakon toga, a uzročno posledična veza sa primenom leka još nije dokazana [31]. Ozbiljan neželjeni događaj označava smrt ispitanika, neposrednu životnu ugroženost, prijem na bolničko lečenje ili prolongiranu hospitalizaciju, onesposobljenost ili trajno oštećenje zdravlja, kongenitalne anomalije/defekti na rođenju, ili neko drugo medicinski značajno stanje.

Neželjeni događaji koji su se pojavili u toku studije su zabeleženi i prijavljeni nadležnoj Agenciji za lekove i medicinska sredstva. Tokom beleženja neželjenih događaja korišćena je standardna medicinska terminologija i označeni su kao „siguran”, ,verovatan”, „moguć”, „malo verovatan" ili „neklasifikovan”, a što se tiče težine kao „blagi”, ,umereni” ili „,teški”, [32].

\section{Protokol studije}

Rezultati ovog istraživanja su samo deo rezultata sponzorisane studije odobrene od strane Nezavisnog etičkog komiteta (Etički komitet Vojnomedicinske akademije, odluka izdata 31/10/2014) i ona je vođena $u$ skladu sa principima Međunardne konferencije za harmonizaciju dobre kliničke prakse (International Conference of Harmonization Good Clinical Practice ICH GCP) i najnovije verzije Helsinške deklaracije (World Medical Association Declaration of Helsinki Ethical Principles for Medical Research Involving Human Subjects, October 19, 2013). Protokol cele studije odobren je od strane Agencije za lekove i medicinska sredstva Srbije (broj 515-04-01565-14-1, od datuma 24/12/2014). Svi učesnici su pre uključenja potpisali pristanak za učešće u studiju.

\section{Statistička analiza}

Statistička analiza podataka urađena je u statističkom program IBM SPSS verzije 26. Kontinualne varijable su predstavljene $\mathrm{u}$ obliku medijane sa interkvartalnim rasponom (od 25. do 75. percentila), a statistička značajnost između dve grupe testirana je Mann-Whitney testom, s obzirom da se radilo o podacima koji nisu ispunjavali zahteve za normalnu raspodelu, koja je proverena na osnovu Kolmogorov-Smirnov testa.

\section{Rezultati}

U tabeli 1 su prikazani demografski podaci ispitanika i rezultati kliničkih i biohemijskih ispitivanja. Značajno veće vrednosti u osoba muškog pola odnosile su se na telesnu težinu, visinu i indeks telesne mase, što je i očekivano. Od laboratorijskih analiza vrednosti broja eritrocita, hemoglobina i hematokrita, kreatinina, kaliju- 
ma, natrijuma i aspartat aminotransferaze su takođe statistički značajno bile veće kod osoba muškog pola. Međutim, sve dobijene vrednosti bile su u opsegu referentnih vrednosti laboratorije u kojoj su ispitivane.

Na grafikonu 1 su prikazane promene koncentracije itrakonazola u plazmi ispitanika u toku 72 časa nakon peroralne promene leka u dozi od $100 \mathrm{mg}$. Statistička analiza Mann-Witney testom je pokazala da su vrednosti medijana koncentracija itrakonazola u muškaraca $\mathrm{u}$ toku celog posmatranog perioda veće nego kod žena, a statističku značajnost dostižu 9, 12 i 24 časa nakon primene leka (ako bi se uporedile doze koje su po kilogramu telesne mase dobijali muškarci i žene, one su za oko $30 \%$ dobijale veću dozu, pa bi farmakokinetske razlike bile još veće).

Tabela 1. Demografski podaci i rezultati kliničkog pregleda i laboratorijskih analiza krvi i urina zdravih ispitanika pre uključivanja u studiju

\begin{tabular}{|l|c|c|c|}
\hline & Muškarci (n=22) & Žene (n=16) & p vrednost* \\
\hline Starost (godine) & $37,50(33,75-41,25)$ & $37,00(32,75-40,75)$ & 0,584 \\
\hline Telesna težina $(\mathrm{kg})$ & $90,00(75,00-93,00)$ & $70,50(63,25-73,75)$ & $<0,001$ \\
\hline Telesna visina $(\mathrm{cm})$ & $181,50(177,50-184,25)$ & $170,50(168,25-174,75)$ & $<0,001$ \\
\hline SKP $(\mathbf{u}$ mirovanju) $(\mathrm{mmHg})$ & $120,00(110,00-121,25)$ & $110,00(102,50-117,50)$ & 0,015 \\
\hline DKP $($ u mirovanju) $(\mathrm{mmHg})$ & $80,00(70,00-81,25)$ & $70,00(70,00-80,00)$ & 0,019 \\
\hline $\begin{array}{l}\text { Srčana radnja (u mirovanju) } \\
\text { (otkucaja/minut) }\end{array}$ & $67,50(62,00-70,50)$ & $71,00(62,25-78,75)$ & 0,351 \\
\hline Eritrociti $\left(\times 10^{12} / \mathrm{L}\right)$ & & & \\
\hline Hemoglobin $(\mathrm{g} / \mathrm{dL})$ & $4,93(4,75-5,15)$ & $4,36(4,18-4,58)$ & $<0,001$ \\
\hline Hematokrit & $144,00(137,50-151,25)$ & $125,50(123,00-130,25)$ & $<0,001$ \\
\hline Leukociti $\left(\mathrm{x} 10^{9} / \mathrm{L}\right)$ & $0,44(0,43-0,46)$ & $0,39(0,38-0,40)$ & $<0,001$ \\
\hline Trombociti $\left(\mathrm{x} 10^{9} / \mathrm{L}\right)$ & $6,46(5,66-7,26)$ & $6,73(5,61-8,34)$ & 0,478 \\
\hline Glukoza $(\mathrm{mmol} / \mathrm{L})$ & $250,50(216,00-276,25)$ & $240,50(222,75-274,00)$ & 0,836 \\
\hline Kreatinin $(\mathrm{mmol} / \mathrm{L})$ & $5,00(4,70-5,30)$ & $4,90(4,50-5,25)$ & 0,389 \\
\hline AST $(\mathrm{IJ} / \mathrm{L})$ & $76,00(68,50-83,25)$ & $51,00(50,00-62,00)$ & $<0,001$ \\
\hline ALT $(\mathrm{IJ} / \mathrm{L})$ & $22,00(20,00-25,00)$ & $20,00(17,25-21,00)$ & 0,016 \\
\hline ALP $(\mathrm{U} / \mathrm{L})$ & $24,00(18,00-31,25)$ & $18,50(15,25-24,50)$ & 0,100 \\
\hline Kalijum $(\mathrm{mmol} / \mathrm{L})$ & $133,00(116,75-166,25)$ & $132,00(113,00-158,00)$ & 0,610 \\
\hline Natrijum $(\mathrm{mmol} / \mathrm{L})$ & $4,40(4,20-4,72)$ & $4,20(4,10-4,63)$ & 0,041 \\
\hline Hloridi $(\mathrm{mmol} / \mathrm{L})$ & $142,50(141,00-144,00)$ & $140,50(140,00-143,00)$ & 0,048 \\
\hline Proteini $(\mathrm{g} / \mathrm{L})$ & $108,00(106,00-109,25)$ & $108,50(107,00-110,00)$ & 0,559 \\
\hline Specifična težina urina & $72,00(70,75-73,25)$ & $71,50(69,00-74,00)$ & 0,699 \\
\hline pH urina & $1,025(1,015-1,026)$ & $1,018(1,010-1,025)$ & 0,219 \\
\hline
\end{tabular}

*- Mann-Whitney test, SKP - sistolni krvni pritisak; DKP - dijastolni krvni pritisak; AST- aspartat amino-transferaza; ALT- alanin amino-transferaza; ALP- alkalna fosfataza; Vrednosti su prikazane kao medijana sa interkvartilnim rasponom (25-75. percentil).

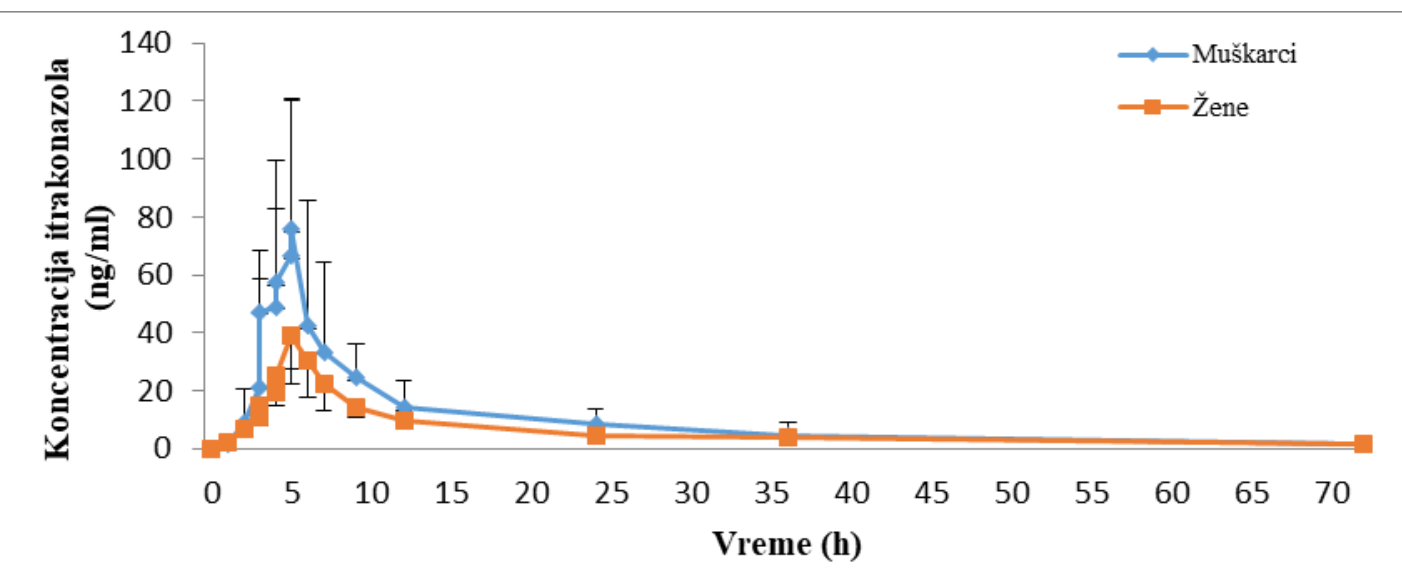

Grafikon 1. Promene koncentracija itrakonazola u plazmi kod muških i ženskih ispitanika u funkciji vremena, od primene leka do 72 časa nakon toga 
U tabeli 2 su prikazani farmakokinetski parametri itrakonazola koji su izračunati iz izmerenih koncentracija leka u plazmi $\mathrm{i}$ to praćenjem $72 \mathrm{~h}$ nakon njegove oralne primene, kod muškaraca i žena.

Naši rezultati ukazuju da su vrednosti medijane za parametar Cmax bile statistički značajno niže kod žena $(\mathrm{p}=0,005)$, što se može zapaziti i na grafikonu 1, a razlika se pokazala statistički značajnom i za drugi pokazatelj resorpcije, PIK, i to i za praćeni period, do $72 \mathrm{~h} \mathrm{i} \mathrm{za}$ ukupnu izračunatu PIK $\left(\mathrm{PIK}_{(0-72)}\right.$ i PIK $(0-\infty) ; \mathrm{p}=0,036$ i $\mathrm{p}=0,036)$. Ove vrednosti su takođe bile statistički značajno niže kod ispitanica. Parametri eliminacije - $T_{1 / 2} i$ $\mathrm{K}_{\mathrm{e}}$ se nisu razlikovali među polovima.

Tabela 2. Farmakokinetski parametri itrakonazola dobijenih kod muških i ženskih ispitanika nakon oralne primene leka u dozi od 100mg

\begin{tabular}{|l|c|c|c|}
\hline & Muškarci (n=22) & Žene (n=16) & p vrednost* \\
\hline Cmax $(\mathrm{ng} / \mathrm{ml})$ & $82,77(36,12-146,23)$ & $42,39(27,24-81,49)$ & 0,005 \\
\hline $\operatorname{Tmax}^{*}(\mathrm{~h})$ & $5,50(5,38-5,500)$ & $5,50(5,00-5,50)$ & 0,421 \\
\hline $\mathbf{P I K}_{(0-72)}(\mathrm{ng} / \mathrm{m}) 1 \times \mathrm{h}$ & $716,32(450,54-1055,50)$ & $466,55(327,93-498,83)$ & 0,036 \\
\hline $\mathbf{P I K}_{(\mathbf{0}-\boldsymbol{c})}(\mathrm{ng} / \mathrm{ml}) \times \mathrm{h}$ & $762,26(483,14-1178,96)$ & $521,23(341,51-797,38)$ & 0,036 \\
\hline $\mathbf{T}_{\mathbf{1 / 2}}(\mathrm{h})$ & $18,48(9,97-23,03)$ & $15,54(9,98-23,37)$ & 0,872 \\
\hline $\mathbf{K}_{\mathbf{e}}(1 / \mathrm{h})$ & $0,04(0,04-0,70)$ & $0,04(0,03-0,40)$ & 0,872 \\
\hline
\end{tabular}

*- Mann-Whitney test, $\mathrm{C}_{\max }$ - maksimalna koncentracija leka u plazmi, $\mathrm{T}_{\max }$ - vreme potrebno da se postigne koncentracija $\mathrm{C}_{\max }, \mathrm{T}_{1 / 2}$-poluvreme eliminacije, $\mathrm{K}_{\mathrm{e}}$ - konstanta eliminacije, $\mathrm{PIK}_{(0-72)}$ - površina ispod krive promena koncentracija leka u plazmi $\mathrm{u}$ funkciji vremena od primene do 72 časa, $\mathrm{PIK}_{(0-\propto)}$ - površina ispod krive koja pokazuje promenu koncentracije leka u plazmi u funkciji vremena, sa procenom za vrednost u beskonačnost. Vrednosti su prikazane kao medijana sa interkvartilnim rasponom (2575. percentil).

Na grafikonu 2 su prikazane promene koncentracija hidroksi-itrakonazola u plazmi zdravih ispitanika oba pola, tokom $72 \mathrm{~h}$ od oralne primene itrakonazola. Medijane koncentracija hidroksi-itrakonazola kod oba pola su bile veće od medijana koncentracija itrakonazola u toku većeg dela perioda praćenje, izuzev na kraju, 36. i
72. sata nakon davanja itrakonazola. Takođe, medijane koncentracija hidroksi-itrakonazola u plazmi muškaraca su bile veće nego u žena u toku celog posmatranog perioda, a od trećeg do 12. sati nakon primene itrakonazola one su bile i statistički značajno veće nego u žena.

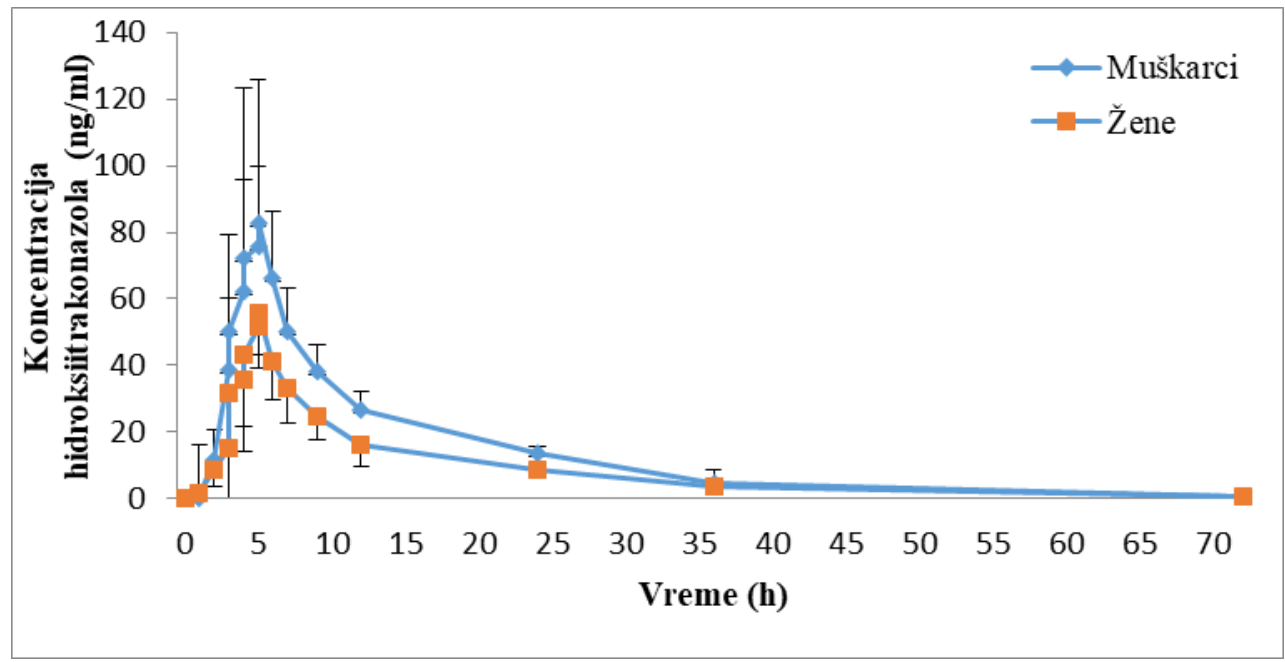

Grafikon 2. Promene koncentracija hidroksi-itrakonazola u plazmi kod muških i ženskih ispitanika u funkciji vremena, od primene itrakonazola, do 72 časa nakon toga

U tabeli 3 su prikazani FK parametri hidroksiitrakonazola koji su izračunati iz izmerenih koncentracija metabolita u krvi i to praćenjem 72 časa nakon peroralne primene itrakonazola, kod muškaraca i žena. I kod hidroksi-itrakonazola su se vrednosti istih FK parametara pokazale statistički značajno različitom kod muškaraca i žena. Parametri resorpcije $-\mathrm{C}_{\max }, \mathrm{PIK}_{(0-72)}$ i PIK $(0-\propto)$ su bili statistički značajno manji u žena $(p=0,004,0,010$ i 0 , 044, redom). Parametri eliminacije, $\mathrm{T}_{1 / 2} \mathrm{i} \mathrm{K}_{\mathrm{e}}$ se nisu razlikovali među polovima. 
Tabela 3. Farmakokinetski parametri hidroksi-itrakonazola dobijeni nakon oralne primene itrakonazola u zdravih dobrovoljaca

\begin{tabular}{|l|c|c|c|}
\hline & Muškarci (n=22) & Žene (n=16) & p vrednost* \\
\hline Cmax $(\mathrm{ng} / \mathrm{ml})$ & $86,69(72,53-147,18)$ & $65,66(49,95-78,37)$ & 0,004 \\
\hline Tmax $_{(\mathrm{h})}$ & $5,50(5,00-5,50)$ & $5,50(5,00-5,50)$ & 0,516 \\
\hline PIK $_{(\mathbf{0}-72)}(\mathrm{ng} / \mathrm{mL}) \times \mathrm{h}$ & $963,15(788,74-1250,07)$ & $644,17(338,80-1004,11)$ & 0,010 \\
\hline PIK $_{(\mathbf{0}-\propto)}(\mathrm{ng} / \mathrm{mL}) \times \mathrm{h}$ & $1069,41(857,90-1371,46)$ & $680,38(451,55-1197,12)$ & 0,044 \\
\hline $\mathbf{T}_{1 / 2}(\mathrm{~h})$ & $11,97(6,24-19,71)$ & $16,65(5,77-22,59)$ & 0,515 \\
\hline $\mathbf{K}_{\mathbf{e}}(1 / \mathrm{h})$ & $0,06(0,04-0,11)$ & $0,04(0,03-0,12)$ & 0,515 \\
\hline
\end{tabular}

*- Mann-Whitney test, Cmax - max koncentracija leka u plazmi, Tmax - vreme potrebno da se postigne koncentracija Cmax, T1/2 poluvreme eliminacije, $\mathrm{Ke}$ - konstanta eliminacije, PIK(0-72) - površina ispod krive promena koncentracija leka u plazmi u funkciji vremena od primene do $72 \mathrm{~h}$, $\operatorname{PIK}(0-\propto)$ - površina ispod krive koja pokazuje promenu koncentracije leka u plazmi $u$ funkciji vremena, sa procenom za vrednost u beskonačnost. Vrednosti su prikazane kao medijana sa interkvartilnim rasponom (2575. percentil).

U toku izvođenja studije, kod jedne osobe ženskog pola nakon uzimanja leka došlo je do neželjenog događaja u vidu mučnine i glavobolje. Simptomi su bili blagog intenziteta i kratkog trajanja, te zbog toga nije isključena iz daljeg toka studije.

\section{Diskusija}

Sve do četrdesetih godina prošlog veka, u terapiji gljivičnih infekcija se koristilo svega nekoliko lekova. Prvo su otkriveni polienski antimikotici, onda azoli, a osamdesetih godina i triazoli [33]. U prvu generaciju triazola spada i itrakonazol, koji inhibiše citohrom P450 enzim lanosterol-14 $\alpha$-demetilazu koja katalizuje reakciju prevođenja lanosterola $\mathrm{u}$ ergosterol, a nedostatak ergosterola u gljivicama u konačnom dovodi do inhibicije njihovog rasta i razmnožavanja $[19,24]$. Površne, subkutane i sistemske gljivične infekcije mogu dovesti do produženog trajanja lečenja osnovne bolesti, hospitalizacije i životne ugroženosti, a i itrakonazol ima svoje mesto u lečenju ovih infekcija [33]. Pored farmakodinamskih svojstava leka važno je poznavati i njegovu farmakokinetiku, a posebno faktore koji utuču na nju, jer je poznato da on spada u grupu hipervarijabilnih lekova, tj onih kod kojih brzina i stepen resorpcije pokazuju veliku varijabilnost ne samo između različitih pacijenata, nego i od doze do doze kod iste osobe, odnosno koeficijent varijacije unutar ispitanika je $30 \%$ ili više [26, 34]. Ovo, kao i nemogućnost da se predvidi koncentracija leka u stanju ravnoteže na osnovu početnog doziranja su glavni faktori koji otežavaju jasno povezivanje između doze leka, plazmatskih koncentracija i kliničke efikasnosti, pa u pacijenata koji se leče itrakonazolom kod teških sistemskih gljivičnih infekcija, kao i kod drugih triazola, koncentracije leka bi trebalo regularno pratiti (terapijski monitoring leka, TDM) da bi se obezbedilo da oni budu dovoljno izloženi leku bilo u profilaktičke, bilo u terapijske svrhe $[25,35,36]$. U faktore koji utiču na farmakokinetiku itrakonazola i postizanje željenih koncentracija u krvi spada i uticaj pola, koji je još uvek nedovoljno poznat $[2,25,37]$. U našem istraživanju vrednosti medijana koncentracija itrakonazola nakon njegove jednokratne peroralne primene u dozi od $100 \mathrm{mg}$ su bile veće u muškaraca nego $\mathrm{u}$ žena u toku ukupnog posmatranog perioda od 72 časa, a statističku značajnost su dostizale 9, 12 i 24 časa nakon primene leka. Takođe, vrednosti medijane za parametar Cmax su bile statistički značajno niže kod žena, a razlika se pokazala statistički značajnom i za drugi pokazatelj resorpcije, PIK, i to i za praćeni period, do 72 časa i za u kupnu izračunatu PIK $\left(\mathrm{PIK}_{(0-\infty)}\right)$. Fiziološki parametri koji utiču na proces resorpcije, a pokazano je da se do izvesne mere razlikuju u muškaraca i žena se mogu se pripisati razlikama u nivou sekrecije želudačne kiseline, pojedine studije navode da je ona niža kod žena $[6,37]$, kao i brzini pražnjenja sadržaja iz želuca i intestinalnom motilitetu koji su veći u muškaraca, pa to govori u prilog veće resorpcije leka u muškaraca [37]. Itrakonazol je izrazito lipofilan lek, slabo rastvorljiv u vodi i jonizuje se samo pri niskom $\mathrm{pH}$, pa prema tome rastvorljiv je u vodi samo u izrazito kiselim uslovima, kao što je u želudačnoj sredini. Kako je kod žena sekrecija hlorovodonične kiseline manja [6, 37], to dovodi do nekompletne disocijacije itrakonazola i njegove slabije resorpcije, koja može biti jedan od uzroka manje koncentracije leka u plazmi u odnosu na muškarce, što smo i mi pokazali. Itrakonazol je supstrat P-glikoproteina (Pgp), membranskog adenozin-tri-fosfat proteina koji se nalazi u velikim koncentracijama u tankom crevu (pored toga u jetri i bubrezima) [38, 39]. On ograničava resorpciju itrakonazola jer ga transportuje iz enterocita nazad u lumen creva. Postoje kontradiktorni rezultati koji se odnose na razlike u polnoj ekspresiji ovog proteina. $\mathrm{Na}$ osnovu analize biopsije dvanaestopalačnog creva kod devedeset jednog zdravog dobrovoljca, pokazano je da nije bilo razlike u crevnoj ekspresiji Pgp između polova [10], ali drugi rezultati ukazuju na uticaj steroidnih hormona (estrogena, estriola i etinil-estradiola) na ekspresiju Pgp-a [9]. Neslaganja postoje i u vezi nivoa ekspresije transportnih protein (pre svega Pgp-a) u jetri i gastrointestinalnom traktu. Međutim, većina studija [14, 40] smatra da je kod žena nivo ekspresije Pgp niži u odnosu na muškarce. U nama dostupnoj literaturi nađena je jedna studija u kojoj su autori pokušali da objasne zašto nisu pokazali biološku ekvivalentnost dva preparata itrakonazola posle peroralne primene (kapsule), koja je ispitivana na 24 zdrava dobrovoljca (12 muškaraca i 12 žena) [38]. S obzirom na to da im je bila poznata hipervarijabilnost itrakonazola, koji ima malu bioraspoloživot i metabolizam izoenzima CYP3A4, 
smatrali su da je i ženski pol ispitanika dodatno uticao na to $\mathrm{i}$ da bi bilo preporučljivo da $\mathrm{u}$ ovakvim studijama učestvuju samo osobe muškog pola. U ovoj studiji Fagiolino i saradnici su pokazali da su kod ženskih ispitanika koje su, kao i muškarci, primile jednokratno oralnu dozu itrakonazola od $200 \mathrm{mg}$, u proseku nađene niže vrednosti $\mathrm{AUC}_{0-48} \mathrm{i}_{\max }$ nego u muškaraca, a $\mathrm{K}_{\mathrm{e}}$ leka su bile slične [38]. Naši rezultati, uključujući i izmerene koncentracije $\mathrm{u}$ plazmi koje su u toku ukupno posmatranog perioda, bile veće u osoba muškog pola ukazuju da su žene bile manje izložene leku, kao i u pomenutoj studiji. Pored već pomenutih razlika na nivou želuca i creva, koje verovatno uslovljavaju manju resorpciju itrakonazola u žena, intenzivnija presistemska eliminacija kod žena, potencijalno doprinose dobijenim razlikama koje se odnose na parametre resorpcije. Dakle, uzrok bi mogle biti polne razlika vezane za enzim CYP3A4 koji metaboliše itrakonazol u jetri. Para i saradnici navode da osobe ženskog pola imaju značajno veću ekspresiju enzima citohroma P450, npr. CYP3A4 enzima, što je veoma značajno zbog mogućnosti indukcije ovih enzima određenim ksenobioticima, ali i zbog povećane stope neželjenih efekata na lekove kod žena [14]. Postoje i druge studije koje potvrđuju ovaj nalaz [41], ali ima i onih kod kojih to nije bio slučaj [42]. Ukoliko prihvatimo značaj ovakvih nalaza, to ide u prilog tvrdnji da žene opsežnije metabolišu CYP3A4-zavisne lekove, uključujući i itrakonazol. Kao primer, poznato je da CYP3A4 metaboliše steroidne hormone $\mathrm{i}$ da je eliminacija metilprednizolona mnogo brža kod žena [43]. Postoje dva mehanizma koja bi mogla objasniti kako dolazi do veće ekspresiji ovog enzima kod žena [44]. Prvi se vezuje za uticaj hormona rasta (HR) [15], a drugi za uticaj ženskih polnih hormona na pregnan-X-receptor (PXR) [16]. Obrazac lučenja hormona rasta $(\mathrm{GH})$ se razlikuje kod muškaraca i žena (pulsni u odnosu na kontinuirani). Tako osobe koje su GH-deficijentne pokazuju različitu ekspresiju enzima CYP3A, zavisno od načina davanja supstitucione terapije. Kada se ovaj hormone daje kontinuirano (imitirajući način lučenja GH kod žena) - povećava se aktivnost CYP3A grupe enzima, a kada se daje u pulsevima (što je način lučenja GH kod muškaraca) - smanjuje se aktivnost istih [15]. Drugi mehanizam se vezuje za uticaj ženskih polnih hormona na PXR. Oni aktiviraju ovaj receptor, a potom nastaje niz supstrata od kojih neki aktiviraju CYP3A grupu enzima [16]. Postoje studije koje su pratile ista svojstva drugih antimikotika iz grupe triazola. Studija Sansone-Parsons i njenih saradnika nije pokazala uticaj pola na farmakokinetiku posakonazola [45], ali ima istraživanja gde se ta razlika ispoljila [46]. U toj studiji, ispitanici muškog pola su imali veću medijanu koncentracije ovog leka. Takođe, uticaj pola je primećen i u studiji sa flukonazolom [47]. U toj studiji su ženski ispitanici imali veće vrednosti $T_{\max }$, $\mathrm{Vd}$ i $\mathrm{C}_{\max }$, i nakon što su ovi parametri normalizovani na telesnu težinu ispitanika. $U$ našem ispitivanju nije bilo razlika u vrednostima medijana $T_{1 / 2}$ i $K_{e}$ itrakonazola, što znači da pol ispitanika nije uslovio promene u eliminaciji ovoga leka, što tvrde i Fagiolino i saradnici [38]. Međutim, mi smo u našem istraživanju išli i korak dalje.
Ispitivane su i koncentracije hidroksi-itrakonazola u koji se itrakonazol metaboliše, primarno u jetri uz pomoć citohrom P450 izoforme CYP3A4 i u njoj nastaje još preko 30 metabolita. U ljudi, hidroksi-itrakonazol postiže veće koncentracije u plazmi od samog itrakonazola, a antimikotična aktivnost im je slična [25]. Kako je ovaj metabolit značajan za celokupnu antigljivičnu aktivnost itrakonazola, TDM itrakonazola bi trebalo da uključi i određivanje njegovog hidroksilovanog metabolite [25]. Međutim, kao i za određivanje koncentracije samog itrakonazola, od veoma velike važnosti je korišćenje savremenih metoda detekcije lekova $\mathrm{u}$ biološkom materijalu, plazmi ili serumu [25]. Već je rečeno da su koncentracije itrakonazola i hidroksi-itrakonazola $u$ plazmi analizirane pomoću validiranih metoda tečne hromatografije sa tandem masenom spektrometrijom (LC-MS/MS), što je u skladu sa savremenim preporukama Evropske agencije za lekove, a već prethodno opisano [28-30]. U našem istraživanju je pokazano da su medijane koncentracija hidroksiitrakonazola i u muškaraca i u žena bile veće od medijana koncentracija itrakonazola $\mathrm{u}$ toku većeg dela perioda praćenje (a poznato je i da je molekulska težina hidroksiitrakonazola veća od te vrednosti za itrakonazol). Ovo je $\mathrm{u}$ skladu sa ranijim nalazima da su plazmatske koncentracije ovog aktivnog metabolita bile više od koncentracija samog leka, čak i duplo, kako u zdravih dobrovoljaca, tako i pacijenata sa neutropenijom, a uz korišćenje tečne hromatografije [25]. Takođe, medijane koncentracija hidroksi-itrakonazola u plazmi muškaraca su bile veće nego u žena u toku 72 sata, a od trećeg do 12 . sata nakon primene itrakonazola one su bile i statistički značajno veće nego u žena. Smatramo da je ovaj nalaz, ne samo odraz već opisane veće koncentracije samog itrakonazola $u$ muškaraca nego $u$ žena $u$ toku posmatranog perioda praćenja, već i opisanih parametara resorpcije koji su statistički značajno manji u osoba ženskog pola. S obzirom na već navedene značajno manje medijane koncentracija hidroksi-itrakonazola $\mathrm{u}$ žena nego u muškaraca, ali i nađene značajno manje medijane za vrednosti parametara resorpcije za ovaj metabolit, to sa velikom verovatnoćom ukazuje da je proces resorpcije itrakonazola, uključujući presistemsku eliminaciju izraženiji u žena, odnosno može da vodi u manju biološku raspoloživost kod njih. U svakom slučaju, veću ekspresiju i/ili aktivnosti izoforme enzima koji metaboliše itrakonazol $\mathrm{u}$ žena bi bilo neophodno potvrditi farmakogenomskim analizama. $\mathrm{Na}$ osnovu izloženog, ovi nalazi bi mogli ići u prilog rezultatima Fagiolinija i saradnika [25], ali ne treba izgubiti iz vida da je ovo istraživanje rađeno samo na 24 ispitanika (12 žena i 12 muškaraca) sa nereplikativnim ukrštenom dizajnom (sa 2 tretmana, 2 perioda i 2 sekvence). Baš zbog već više puta pominjane hipervarijabilnosti leka, velike svetske agencije za lekove, kao što su Evropska agencija za lekove i Američka Uprava za hranu i lekove, zahtevaju značajno veći broj ispitanika koji primaju lekove koji se koriste u studiji uporedne biološke raspoloživosti (biološke ekvivalentnosti) u višestruko unakrsnom ispitivanju [48-51]. 
Kao rezultat, $u$ našem prethodno urađenom randomizovanom, delimično ponovljenom, trostruko ukrštenom ispitivanje sa dva tretmana, tri sekvence i tri perioda, nakon peroralne primene $100 \mathrm{mg}$ itrakonazola $\mathrm{u}$ 38 zdravih ispitanika pokazali smo da su, iako su bile uključene i osobe muškog i ženskog pola, dve ispitivane formulacije kapsula itrakonazola od 100mg bile biološki ekvivalentne [30]. To su pokazali i drugi autori, koji su modifikovali uobičajeni dizajn i broj ispitanika za studije biološke ekvivalentnosti lekova, odnosno registraciju novog generičkog leka za tržište [52].

Sto se tiče neželjenih efekata, u ovoj studiji je samo jedan ženski dobrovoljac ispoljio neželjene efekte $u$ vidu mučnine, povraćanja i glavobolje. Najčešći neželjeni efekti itrakonazola su oni koji su vezani za gastrointestinalni trakt (mučnina, povraćanje, dijareja, anoreksija, suvoća usta i opstipacija) [53]. Učestalost neželjenih efekata raste sa povećanjem doze leka i značajno je veća ako je dnevna doza preko 400mg/dan [54,55]. U studiji Lestnera i saradnika je pokazano da se sa smanjenjem doze najbrže povlače gastrointestinalni neželjeni efekti, dok su, kod nekih pacijenata, simptomi poput tremora i periferne neuropatije trajali i do 6 meseci [56]. U svakom slučaju naši rezultati su u skladu sa smernicama Evropske agencije za lekove, po kojoj su hipervarijabilni lekovi, uključujući i itrakonazol, generalno bezbedni lekovi, pa je zato i prihvaćeno da granice prosečnih vrednosti pokazatelja biološke raspoloživosti za testirani i referentni lek za parameter Cmax bude proširen čak na raspon od 72,15-138,59\% [30, 48, 50, 51].

\section{Ograničenja studije}

U studiji smo imali nešto veći broj muških nego ženskih dobrovoljaca, ali je ukupan broj ispitanika bio veći nego u do sada izvedenim studijama koje su sa istim ciljem uključivale zdrave dobrovoljce, pa stoga smatramo da su dobijeni rezultati, sa odgovarajućom statističkom analizom, kao i izvedeni zaključci, u potpunosti validni.

\section{Zaključak}

Rezultati ove studije su pokazali da su u zdravih ispitanica nakon per os upotrebe kapsule itrakonazola u dozi od $100 \mathrm{mg}$ nađene niže vrednosti plazmatskih koncentracija i itrakonazola i metabolita hidroksiitrakonazola tokom posmatranog perioda od 72 časa. Medijane vrednosti parametara $\mathrm{C}_{\max }$, PIK $_{(0-72)}$ i PIK $(0-\infty)$ itrakonazola su bile statistički značajno manje u žena nego u muškaraca. Žene su nakon peroralne primene leka u manjem stepenu izložene itrakonazolu i njegovom aktivnom metabolitu u odnosu na muškarce, kao rezultat manje resorpcije ovog leka usled presistemske eliminacije, uključujući i intenzivniji metabolizam pri prvom prolazu usled veće ekspresije $\mathrm{i} / \mathrm{ili}$ aktivnosti izoforme enzima koji ga metaboliše, a što bi bilo neophodno potvrditi farmakogenomskim analizama.

Sukob interesa: autori izjavljuju da nemaju sukob interesa.

\section{Izjava zahvalnosti i finansiranje}

Zahvaljujemo kompaniji Slaviamed d.o.o. koja je dala odobrenje za korišćenje podataka o farmakokinetici itrakonazola koji su dobijeni u okviru akademskog istraživanja, a koje je proisteklo iz studije koja je bila sponzorisana od strane ove farmaceutske kompanije.

\section{Literatura}

1. Ritter J, Flower R, Henderson G, Loke YK, MacEwan D, Rang H. Rang and Dale's Pharmacology. 9th edition. Amsterdam: Elsevier, 2019.

2. Geller SE, Koch AR, Roesch P, Filut A, Hallgren E, Carnes $\mathrm{M}$. The more things change, the more they stay the same: a study to evaluate compliance with inclusion and assessment of women and minorities in randomized controlled trials. Acad Med. 2018; 93(4): 630-635. doi: 10.1097/ACM. 0000000000002027. PMID: 29053489; PMCID: PMC5908758.

3. Franconi F, Campesi I. Sex Impact on Biomarkers, Pharmacokinetics and Pharmacodynamics. Curr Med Chem. 2017; 24(24): 2561-2575. doi: 10.2174/0929867323666161003124616. PMID: 27697075.

4. Zucker I, Prendergast BJ. Sex differences in pharmacokinetics predict adverse drug reactions in women. Biol Sex Differ. 2020; 11(1): 32. doi: 10.1186/s13293-020-00308-5.

5. Labots G, Jones A, de Visser SJ, Rissmann R, Burggraaf J. Gender differences in clinical registration trials: is there a real problem? Br J Clin Pharmacol. 2018; 84(4): 700-707. doi: 10.1111/bcp.13497. PMID: 29293280; PMCID: PMC5867082.

6. Islam MM, Iqbal U, Walther BA, Nguyen PA, Li YJ, Dubey NK, Poly TN, Masud JHB, Atique S, SyedAbdul S. Gender-based personalized pharmacotherapy: a systematic review. Arch Gynecol Obstet. 2017;295(6):1305-1317. doi: 10.1007/s00404-0174363-3. PMID: 28378180.

7. Al-Shboul OA, Nazza MS, Mustafa AG, Al-Dwairi AN, Alqudah MA, Abu Omar A, et al. Estrogen relaxes gastric muscle cells via a nitric oxide- and cyclic guanosine monophosphate-dependent mechanism: A sex-associated differential effect. Experimental and Therapeutic Medicine. 2018; 16(3): 1685-1692.https://doi.org/10.3892/etm.2018.6406.

8. Jin H, Wen G, Deng S, Wan S, Xu J, Liu X, et al. Oestrogen upregulates the expression levels and functional activities of duodenal mucosal CFTR and SLC26A6. Exp Physiol. 2016; 101: 13711382. https://doi.org/10.1113/EP085803.

9. Chen C, Lee M-H, Weng C-F, Leong MK. Theoretical Prediction of the Complex P-Glycoprotein Substrate Efflux Based on the Novel Hierarchical Support Vector Regression Scheme. Molecules. 2018; 23(7): 1820. https://doi.org/10.3390/molecules23071820. 
10.Paine MF, Ludington SS, Chen ML, Stewart PW, Huang SM, Watkins PB. Do men and women differ in proximal small intestinal CYP3A or P-glycoprotein expression? Drug Metab Dispos. 2005; 33(3):426-433.

11.Lin YY, Chen HC, Lai WS, Wu LW, Wang CH, Lee JC, et al. Gender Differences in the Association between Moderate Alcohol Consumption and Hearing Threshold Shifts. Sci Rep. 2017; 7: (2201): 1-7. https://doi.org/10.1038/s41598-017-02426-4.

12.Brinkman-Van der Linden CM, Havenaar EC, Van Ommen CR, Van Kamp GJ, Gooren LJ, Van Dijk W. Oral estrogen treatment induces a decrease in expression of sialyl Lewis $\mathrm{x}$ on alpha 1-acid glycoprotein in females and male-to-female transsexuals. Glycobiology. 1996; 6(4): 407-412.

13. Wiegratz I, Kutschera E, Lee JH, Moore C, Mellinger $\mathrm{U}$, Winkler UH, et al. Effect of four different oral contraceptives on various sex hormones and serumbinding globulins. Contraception. 2003; 67(1): 25-32.

14.Para O, Crispino P, Barone N, Macis S, Airasca L, Gnerre $P$, et al. Sex differences in adverse drug reaction and liver disease. Italian Journal of Medicine. 2018; 12(1), 15. doi:10.4081/itjm.2018.893.

15.Lu M, Flanagan JU, Langley RJ, Hay MP and Perry JK. Targeting growth hormone function: strategies and therapeutic applications. Sig Transduct Target Ther. 2019; 4(3): 1-11. https://doi.org/ 10.1038/s41392-019-0036-y.

16. Handschin C, Meyer UA. Induction of drug metabolism: the role of nuclear receptors. Pharmacol Rev. 2003; 55(4): 649-673. doi: 10.1124/pr.55.4.2. PMID: 14657421.

17.Askhi M. Valodara and Kaid Johar SR. Sexual Dimorphism in Drug Metabolism and Pharmacokinetics. Current Drug Metabolism. 2019; 20: 1154. https://doi.org/10.2174/138920022066619102109490 6.

18. Gross JL, Friedman R, Azevedo MJ, Silveiro SP, Pecis M. Effects of age and sex on glomerular filtration rate measured by 51Cr-EDTA. Braz J Med Biol Res. 1992; 25(2): 129-134. PMID: 1339508.

19. Singh S, Chandra U, Anchan VN, Verma P, Tilak R. Limited effectiveness of four oral antifungal drugs (fluconazole, griseofulvin, itraconazole and terbinafine) in the current epidemic of altered dermatophytosis in India: results of a randomized pragmatic trial. Br J Dermatol. 2020;183(5):840-846. doi: 10.1111/bjd.19146. PMID: 32538466.

20.Lindsay J, Sandaradura I, Wong K, Arthur C, Stevenson W, Kerridge I, et al. Serum levels, safety and tolerability of new formulation SUBA-itraconazole prophylaxis in patients with haematological malignancy or undergoing allogeneic stem cell transplantation. J Antimicrob Chemother. 2017; 72(12): 34143419. doi: 10.1093/jac/dkx295. PMID: 28961894.

21.Schwartz IS, Wasserman S. Itraconazole and antiretroviral therapy: strategies for empirical dosing. Lancet Infect Dis. 2017;17(11):1122-1123. doi: 10.1016/S1473-3099(17)30568-6. PMID: 29115262.
22.Nomani H, Moghadam M, Emami SA, Mohammadpour AH, Johnston TP, Sahebkar A. Drug interactions of cola-containing drinks. Clinical Nutrition. 2019; 38(6):2545-2551. DOI: https://doi.org/10.1016/ j.clnu.2019.01.029.

23.Van Peer A, Woestenborghs R, Heykants J, Gasparini $\mathrm{R}$, Gauwenbergh G. The effects of food and dose on the oral systemic availability of itraconazole in healthy subjects. Eur J Clin Pharmacol. 1989; 36(4): 423426. doi: 10.1007/BF00558308. PMID: 2544431.

24. Thummel K, Shen D, Isoherranen N. Design and Optimization of Dosage Regimens: Pharmacokinetic Data. In: Brunton L, Hilal-Dandan R, Knollmann B. Goodman \& Gilman's The Pharmacological Basis of therapeutics. 13th Edition. New York: McGraw-Hill Education; 2018: 1325-1379.

25. Nakamura Y, Matsumoto K, Sato A, Morita K. Effective plasma concentrations of itraconazole and its active metabolite for the treatment of pulmonary aspergillosis. J Infect Chemother. 2020;26(2):170174. doi: 10.1016/j.jiac.2019.08.002. PMID: 31481305.

26.Endrenyi L, Tothfalusi L. Bioequivalence for highly variable drugs: regulatory agreements, disagreements, and harmonization. J Pharmacokinet Pharmacodyn. 2019; 46(2): 117-126. doi: 10.1007/s10928-01909623-w. PMID: 30798390.

27. Guideline on the investigation of bioequivalence. European Medicines Agency (EMA). Available from: http://www.ema.europa.eu/docs/en_GB/document_lib rary/Scientific_guideline/2010/01/WC500070039.pdf.

28.Francis Micheal, Balamurali MM, Mohanlal Sayana, \& Rajendra Prasad M. Assessment of comparative bioavailability of Itraconazole capsule $100 \mathrm{mg}$ under fasting conditions by average bioequivalence (ABE), population bioequivalence (PBE) and individual bioequivalence (IBE) approaches. IJRPS. 2019;10(4): 3339-3345.

DOI: https://doi.org/10.26452/ijrps.v10i4.1643.

29.Patni AK, Monif T, Khuroo AH, Iyer SS, Jain R, Kumar S, et al. Determination of pharmacokinetics of itraconazole in healthy Indian subjects under fed condition and incurred sample analysis using a validated liquid chromatography tandem mass spectrometric method. Clinic Res Regul Aff. 2012; 29: 35-40. DOI: https://doi.org/10.3109/10601333.2012.668192.

30.Dragojević-Simić V, Kovačević A, Jaćević V, Rančić $\mathrm{N}$, Đordjević S, Kilibarda V, et al. Bioequivalence study of two formulations of itraconazole $100 \mathrm{mg}$ capsules in healthy volunteers under fed conditions: a randomized, three-period, reference-replicated, crossover study. Expert Opin Drug Metab Toxicol. 2018; 14(9): 979 - 988 . doi: 10.1080/17425255.2018.1503649. PMID: 30028640.

31.Guideline Clinical Safety Data Management: Definitions AND Standards FOR Expedited Reporting E2A. International Conference on Harmonization of Technical Requirement for 
Registration of Pharmaceuticals for Human use (ICH).

Available from: https://www.ich.org/fileadmin/

Public_Web_Site/ICH_Products/guidelines/

Efficacy/E2A/Step4/E2A_Guideline.pdf.

32.The use of the WHO-UMC system for standardized case causality assessment. The Uppsala Monitoring Centre. Available from: https://www.whoumc.org/ Media/2768/standardised-case-casualty-assessment. Pdf.

33. Scorzoni L, de Paula e Silva ACA, Marcos CM, Assato PA, de Melo WCMA, de Oliveira HC, et al. Antifungal Therapy: New Advances in the Understanding and Treatment of Mycosis. Front Microbiol. 2017;8:36.doi: 10.3389/fmicb.2017.00036. PMID: 28167935 ; PMCID: PMC5253656.

34.Hwang JG, Yu KS, Lee S. Comparison of the Pharmacokinetics of Highly Variable Drugs in Healthy Subjects Using a Partial Replicated Crossover Study: A Fixed-Dose Combination of Fimasartan $120 \mathrm{mg}$ and Atorvastatin $40 \mathrm{mg}$ versus Separate Tablets. Drug Des Devel Ther. 2020; 14: 1953-1961. doi: 10.2147/DDDT.S233732. PMID: 32546962; PMCID: PMC7246321.

35. Allegra S, Fatiguso G, De Francia S, Favata F, Pirro E, Carcieri C, et al. Pharmacokinetic evaluation of oral itraconazole for antifungal prophylaxis in children. Clin Exp Pharmacol Physiol. 2017; 44(11): 1083-1088. doi: 10.1111/1440-1681.12822. PMID: 28744925.

36.John J, Loo A, Mazur S, Walsh TJ. Therapeutic drug monitoring of systemic antifungal agents: a pragmatic approach for adult and pediatric patients. Expert Opin Drug Metab Toxicol. 2019; 15(11): 881-895. doi: 10.1080/17425255.2019.1671971. PMID: 31550939.

37.Zucker, I., Prendergast, B.J. Sex differences in pharmacokinetics predict adverse drug reactions in women. Biol Sex Differ. 2020; 11: 32. https://doi.org/10.1186/s13293-020-00308-5.

38. Fagiolino P, González N, Vázquez M, Eiraldi R. Itraconazole Bioequivalence Revisited: Influence of Gender on Highly Variable Drugs. The Open Drug Metabolism Journal. 2007; 1(1): 7-13. DOI: $10.2174 / 1874073100701010007$.

39.Li M, de Graaf IA, Siissalo S, de Jager MH, van Dam A, Groothuis GM. The Consequence of Drug-Drug Interactions Influencing the Interplay between PGlycoprotein and Cytochrome P450 3a: An Ex Vivo Study with Rat Precision-Cut Intestinal Slices. Drug Metab Dispos. 2016; 44(5): 683-691. doi: 10.1124/dmd.115.068684. PMID: 26932816.

40.Davis M. Gender differences in p-glycoprotein: drug toxicity and response. J Clin Oncol. 2005; 23(26):6439-40. doi: 10.1200/JCO.2005.01.9232. PMID: 16155032.

41.Trenaman SC, Rideout M, Andrew MK. Sex and gender differences in polypharmacy in persons with dementia: A scoping review. SAGE Open Med. 2019; 7: 2050312119845715 . doi: $10.1177 /$
2050312119845715. PMID: 31041100; PMCID: PMC6477755.

42.George J, Byth K, Farrell GC. Age but not gender selectively affects expression of individual cytochrome P450 proteins in human liver. Biochem Pharmacol. 1995; 50(5): 727-730. doi: 10.1016/00062952(95)00192-3. PMID: 7669077.

43. Meffin PJ, Brooks PM, Sallustio BC. Alterations in prednisolone disposition as a result of time of administration, gender and dose. Br J Clin Pharmacol. 1984; 17(4): 395-404. doi: 10.1111/j.13652125.1984.tb02363.x. PMID: 6721985; PMCID: PMC1463403.

44.Sakuma T, Kawasaki Y, Jarukamjorn K, Nemoto N. Sex differences of drug-metabolizing enzyme: Female Predominant Expression of Human and Mouse Cytochrome P450 3A Isoforms. Journal of Health Science. 2009; 55(3): 325-337.

45.Sansone-Parsons A, Krishna G, Simon J, Soni P, Kantesaria B, Herron J, et al. Effects of Age, Gender, and Race/Ethnicity on the Pharmacokinetics of Posaconazole in Healthy Volunteers. Antimicrob Agents Chemother. 2007;51(2):495-502. doi: 10.1128/AAC.00472-06. PMID: 17101682; PMCID: PMC1797752.

46. Allegra S, Fatiguso G, De Francia S, Favata F, Pirro $\mathrm{E}$, Carcieri $\mathrm{C}$, et al. Evaluation of Posaconazole Pharmacokinetics in Adult Patients with Invasive Fungal Infection. Biomedicines. 2017; 5(4): 66. doi: 10.3390/biomedicines5040066. PMID: 29156624; PMCID: PMC5744090.

47.Carrasco-Portugal MC, Flores-Murrieta FJ. Gender Differences in the Oral Pharmacokinetics of Fluconazole. Clin Drug Invest. 2007; 27(12): 851-855. doi: 10.2165/00044011-200727120-00007. PMID: 18020543.

48. Tothfalusi L, Endrenyi L, Arieta AG. Evaluation of bioequivalence for highly variable drugs with scaled average bioequivalence. Clin Pharmacokinet. 2009; 48(11): 725-743. doi: 10.2165/11318040-00000000000000. PMID: 19817502.

49.Hwang JG, Yu KS, Lee S. Comparison of the Pharmacokinetics of Highly Variable Drugs in Healthy Subjects Using a Partial Replicated Crossover Study: A Fixed-Dose Combination of Fimasartan 120 $\mathrm{mg}$ and Atorvastatin $40 \mathrm{mg}$ versus Separate Tablets. Drug Des Devel Ther. 2020; 14: 1953-1961. doi: 10.2147/DDDT.S233732. PMID: 32546962; PMCID: PMC7246321.1083-1088. doi: 10.1111/14401681.12822. PMID: 28744925.

50.Allegra S, Fatiguso G, De Francia S, Favata F, Pirro E, Carcieri C, et al. Pharmacokinetic evaluation of oral itraconazole for antifungal prophylaxis in children. Clin Exp Pharmacol Physiol. 2017; 44(11): 1083-1088. doi: 10.1111/1440-1681.12822. PMID: 28744925. 
51.Dragojević-Simić V, Kovačević A, Jaćević V, Rančić N, Djordjevic S, Kilibarda V, et al. Bioequivalence study of two formulations of itraconazole $100 \mathrm{mg}$ capsules in healthy volunteers under fed conditions: a randomized, three-period, reference-replicated, crossover study. Expert Opin Drug Metab Toxicol. 2018; 14(9): 979-988. doi: 10.1080/17425255.2018.1503649. PMID: 30028640.

52.Public Assessment Report. Decentralised Procedure Itraconazole $100 \mathrm{mg}$ Capsules. Last update 2012. Available from: https://documen.tips/documents/public-assessmentreport-decentralised-procedure-public-assessmentreport.html.

53.Tucker R, Haq Y, Denning D, Stevens D. Adverse events associated with itraconazole in 189 patients on chronic therapy. J Antimicrob Chemother. 1990; 26(4): $\quad 561-566 . \quad$ DOI: https://www.doi.org/10.1093/jac/26.4.561.

54.De Doncker P, Pande S, Richarz U, Garodia N. Itraconazole: What clinicians should know? Indian J Drugs Dermatol. 2017; 3: 4-10. DOI: 10.4103/ijdd.ijdd_20_17.

55.Cartledge J, Midgely J, Gazzard B. Itraconazole solution: higher serum drug concentrations and better clinical response rates than the capsule formulation in acquired immunodeficiency syndrome patients with candidosis. J Clin Pathol. 1997; 50(6): 477-480. doi: 10.1136/jcp.50.6.477. PMID: 9378812; PMCID: PMC499974.

56.John J, Loo A, Mazur S \& Walsh TJ. Therapeutic drug monitoring of systemic antifungal agents: a pragmatic approach for adult and pediatric patients. Expert Opin Drug Metab Toxicol. 2019; 15(11): 881-895. doi: 10.1080/17425255.2019.1671971. PMID: 31550939. 
ORIGINAL ARTICLE

\title{
GENDER DIFFERENCES IN CONCENTRATION OF ITRACONAZOLE AND HYDROXYITRACONAZOLE
}

\author{
Tijana STANOJKOVIĆ , Milijana MILJKOVIĆ $^{l, 2}$, Nemanja RANČIĆ ${ }^{l, 2}$, Aleksandra KOVAČEVIĆ ${ }^{1,2}$, \\ Viktorija DRAGOJEVIĆ-SIMIĆ ${ }^{1,2}$
}

${ }^{1}$ Faculty of Medicine, Military Medical Academy, University of Defense, Belgrade, Serbia; ${ }^{2}$ Centre for Clinical Pharmacology, Military Medical Academy

\begin{abstract}
Introduction: Itraconazole is an antifungal drug belonging to the triazole group. After oral application, it is rapidly absorbed, but its bioavailability is reduced due to an intensive first-pass through the liver metabolism effect. A large number of metabolites (the most important of which is hydroxyitraconazole) are produced by isoform CYP3A4 of cytochrome P450. The variability of itraconazole pharmacokinetics is the result of numerous factors that have not yet been fully clarified. Our study aimed to investigate the influence of gender on itraconazole and hydroxyitraconazole plasma concentrations in healthy adults after an oral application of a single dose of itraconazole.

Methods: Pharmacokinetic analysis was performed after oral administration of itraconazole in a single dose of 100 $\mathrm{mg}$ to 22 male and 16 female healthy volunteers. Blood samples were collected before taking the drug and at appropriate time intervals up to 72 hours later. Itraconazole and hydroxyitraconazole concentrations were determined using a validated liquid chromatography method with mass spectrometric detection (LC-MS/MS) and their pharmacokinetic parameters were calculated by using the Kinetica programme, version 5.0: Cmax, Tmax, PIK $(0-72), \mathrm{PIK}_{(0-\infty)}, \mathrm{T}_{1 / 2}$, and Ke.

Results: The median values of both itraconazole and hydroxyitraconazole were lower in women in comparison to men during the whole period of observation. Moreover, median values of Cmax, $\mathrm{PIK}_{(0-72)}$ and $\mathrm{PIK}_{(0-\infty)}$ parameters were also significantly lower in women, concerning both itraconazole ( $\mathrm{p}=0.005,0.036$ and 0.036 , respectively) and its metabolite ( $\mathrm{p}=0.004,0.010$ and 0.044 , respectively). Elimination parameters $-\mathrm{T}_{1 / 2}$ and $\mathrm{K}_{\mathrm{e}}$ did not differ between genders.

Conclusion: Women were less exposed to itraconazole and its active metabolite than men following an oral application of the drug, possibly as a result of lower bioavailability due to a more intense pre-systemic metabolism, as a result of a higher expression and/or activity of the isoform enzyme, which metabolises itraconazole, and which would need to be confirmed by pharmacogenomic analysis.
\end{abstract}

Keywords: itraconazole; hydroxy-hydroxyitraconazole; plasma concentrations, healthy subjects, gender. 